\author{
irAs Extansion
}

\title{
Giant Reed (Arundo donax): Biology, Identification and Management ${ }^{1}$
}

Kurt Vollmer, Curtis Rainbolt, and Jason Ferrell ${ }^{2}$

\section{Introduction}

Giant reed (Arundo donax L.) (Figure 1) is a tall perennial grass thought to be native to the freshwater regions of Eastern Asia. It has been cultivated for use as building material, erosion control, and windbreak throughout the Middle East and Mediterranean region for thousands of years, and is currently widespread in southern Europe, Northern Africa, the Middle East, Australia, South America, and North America. The majority of commercially produced giant reed is grown in the Mediterranean to make reeds for musical instruments.

In the 1820s, it was introduced in California for use as a flood control agent, but has since escaped and become a major invasive weed problem in California and Texas watersheds. Giant reed can be found throughout the southern United States and as far north as Maryland, but the date and location of its initial introduction in the eastern United States is unknown.

With renewed interest in bioenergy production in the United States and throughout the world, giant reed is receiving considerable attention because of its ability to quickly accumulate high amounts of biomass. Although giant reed has been present in Florida for many years, it has not become a problem species. However, because of its growth characteristics and competitive ability it should be monitored closely.

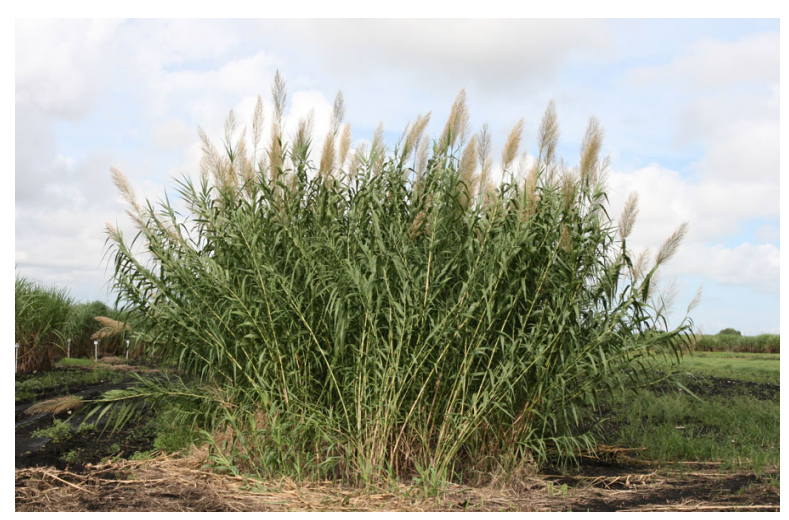

Figure 1. Giant reed growing near Belle Glade, FL. Credits: Curtis Rainbolt, UF/IFAS

1. This document is SS AGR 301, one of a series of the Agronomy Department, Florida Cooperative Extension Service, Institute of Food and Agricultural Sciences, University of Florida. Original publication date March 2008. Visit the EDIS Web Site at http://edis.ifas.ufl.edu.

2. Kurt Vollmer, graduate assistant, Agronomy Department; Curtis Rainbolt, assistant professor, Agronomy Department; Jason Ferrell, assistant professor, Agronomy Department; Florida Cooperative Extension Service, Institute of Food and Agricultural Sciences, University of Florida, Gainesville, FL 32611. The use of trade names in this publication is solely for the purpose of providing specific information. UF/IFAS does not guarantee or warranty the products named, and references to them in this publication does not signify our approval to the exclusion of other products of suitable composition. All chemicals should be used in accordance with directions on the manufacturer's label.

The Institute of Food and Agricultural Sciences (IFAS) is an Equal Opportunity Institution authorized to provide research, educational information and other services only to individuals and institutions that function with non-discrimination with respect to race, creed, color, religion, age, disability, sex, sexual orientation, marital status, national origin, political opinions or affiliations. U.S. Department of Agriculture, Cooperative Extension Service, University of Florida, IFAS, Florida A. \& M. University Cooperative Extension Program, and Boards of County Commissioners Cooperating. Larry Arrington, Dean 


\section{Biology and Identification}

Giant reed is a large, clumping, perennial grass with hollow stems that are 1/4 to 2" thick (Figure 2). The stems have a cane-like (Figure 3) appearance that is similar to bamboo. Mature stands are typically 12-16' in height, but stands over 20' high have been reported. Leaves typically have a stiff or erect habit, are alternate, and, at maturity, are about $2 "$ wide and 24-36" long. Leaves have smooth surfaces, are rounded at the base, and taper to a long point (Figure 4). The ligules are large and papery with small hairs along the margin. Leaf color is typically blue-green, but in some clones the immature leaves range from variegated to almost complete white (Figure 5). The underground portion of giant reed consists of an extensive network of rhizomes and fibrous tap roots. Rhizomes and root masses are light brown in color (Figure 6). The inflorescence is an erect feathery spike 1' to 2' long ranging from whitish to brown in color depending on maturity (Figure 7). Spikelets are stalked and solitary and the flowers have long silky awns. Although giant reed can produce seed under some conditions, there is no evidence that the seeds are viable. Consequently, reproduction is strictly from stalk and rhizome pieces. Giant reed can grow from rhizome fragments as small as 1".

Common reed (Phragmites australis) (Figure 8) may be mistaken for giant reed, but is typically smaller in stature and has a looser silvery-tan inflorescence.

Giant reed prefers wet conditions, but can be found in areas ranging from moist, well drained soils to areas with a water table near the surface. It is also commonly found along roadsides and stream banks. Once established in wetland and riparian habitats, giant reed produces monotypic stands that displace native species. Dead and dry stands can pose a fire hazard. Giant reed also interferes with rivers and lakes by increasing sedimentation and narrowing water channels which leads to flooding and erosion.

\section{Management}

Giant reed growth can be greatly suppressed by repeated close mowing. To prevent regrowth, mown plant material should be removed from the site. Repeated tillage can also be used to deplete root and rhizome masses, but care should be taken to avoid spreading rhizomes to un-infested areas. The key to eradicating established populations of giant reed is killing the root and rhizome mass. This requires treating the plant with a systemic herbicide at appropriate times of the year to ensure translocation to the roots and rhizomes. Glyphosate (2 to 5\% solution) applied to leaves after the crop has flowered has been effective in California. Additionally, applications of imazapyr (Arsenal, and others) at 2\% or imazapyr $0.5 \%+$ glyphosate at $2 \%$ may also be effective. Regardless which herbicide is used, repeat applications will likely be necessary. Cut stem treatments can be effective if glyphosate is applied within minutes of cutting the stem. When controlling giant reed with herbicides in aquatic areas, make sure that the product is registered for this use.

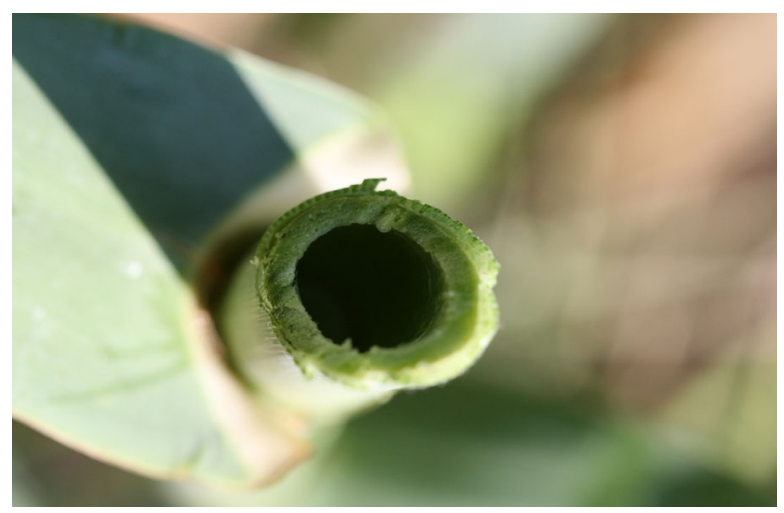

Figure 2. Hollow stem of giant reed. Credits: Curtis Rainbolt, UF/IFAS

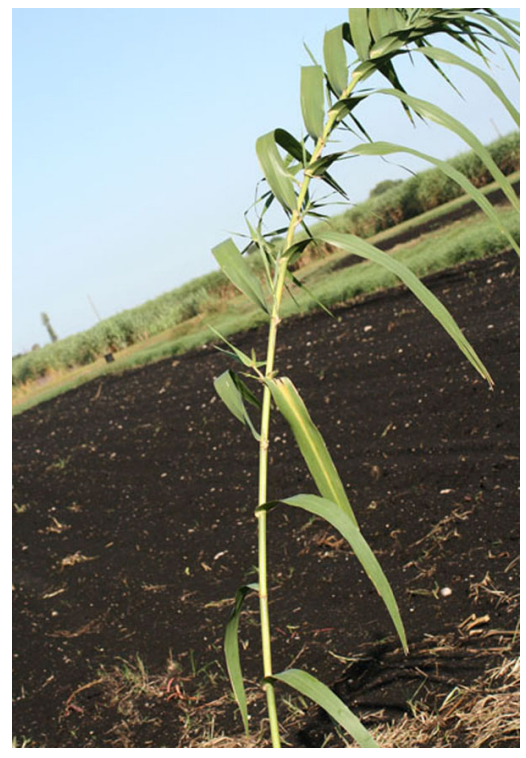

Figure 3. Cane-like stem of mature giant reed. Credits: Curtis Rainbolt, UF/IFAS 


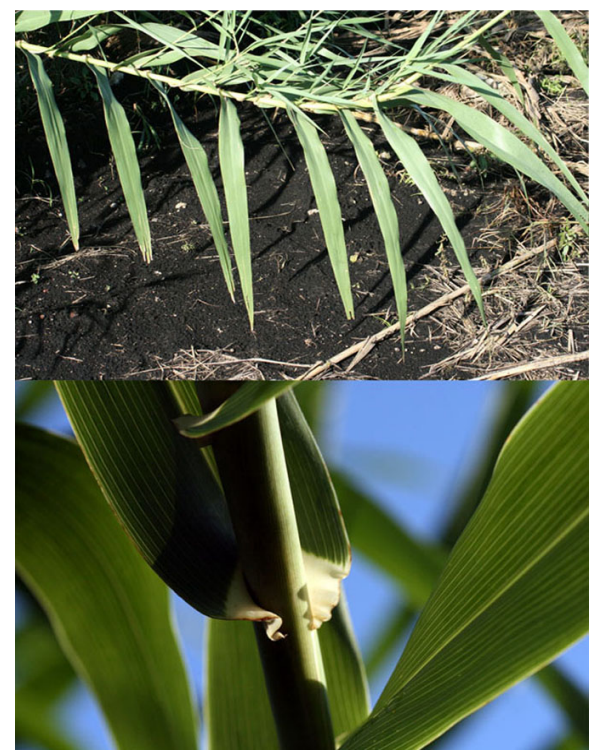

Figure 4. Giant reed leaf. Credits: Curtis Rainbolt, UF/IFAS

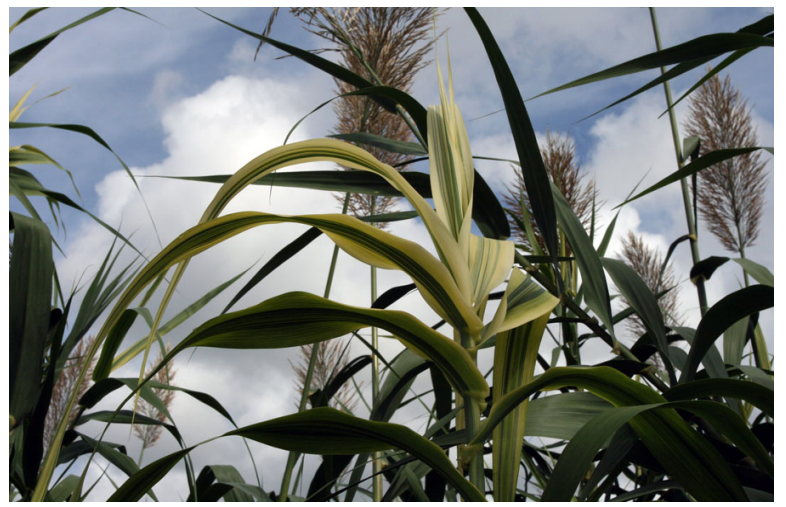

Figure 5. Leaves of variegated giant reed. Credits: Curtis Rainbolt, UF/IFAS

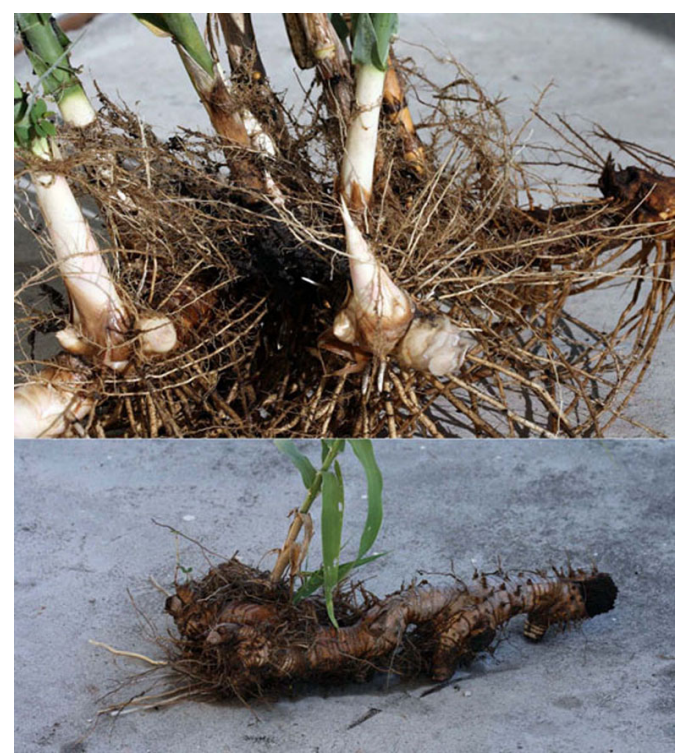

Figure 6. Rhizomes from giant reed. Credits: Curtis Rainbolt, UF/IFAS

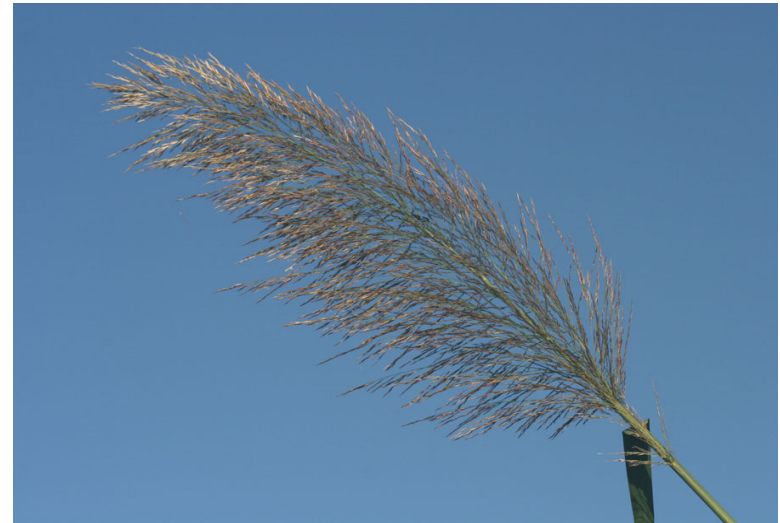

Figure 7. Large plume-like inflorescence of giant reed. Credits: Curtis Rainbolt, UF/IFAS

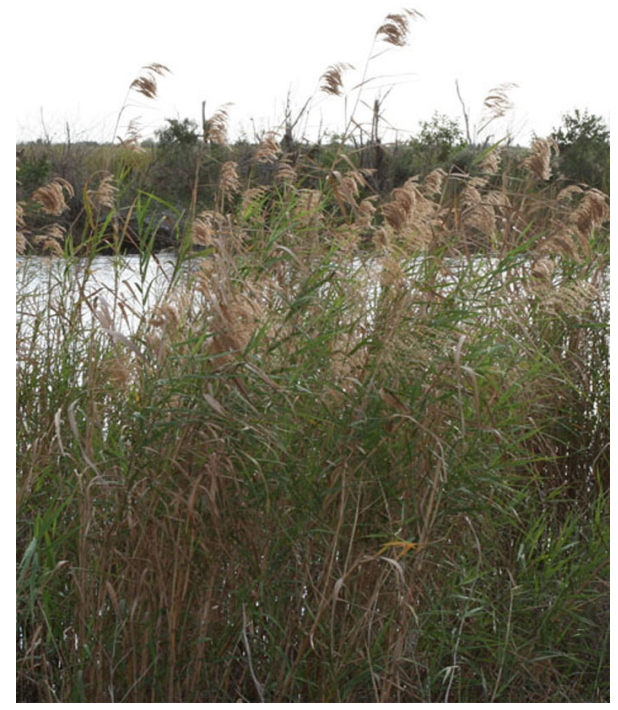

Figure 8. Common reed. Credits: Ann Murray, UF/IFAS

\section{Bibliography}

Arundo donax (grass). Global Invasive Species Database. http://www.issg.org

Bell, Gary P. 1997. Ecology and Management of Arundo donax, and approaches to riparian habitat restoration in Southern California. In Brock, J., Wade, M., Pysek, P., Green, D. (eds.) Plant invasions: Studies from No. America and Europe. Pp. 103-113.

Boose, A.B. and J.S. Holt. 1999. Environmental effects on asexual reproduction in Arundo donax. Weed Research (Oxford), 39:2, pp. 117-127.

Christou, M., 2001. Giant reed in Europe. In: Proceedings of the First World Conference on 
Biomass for Energy and Industry, Sevilla, Spain, 5-9

June 2000, pp. 2089-2091.

Conservation Alliance Alien Plant Working

Group. 2005. Fact Sheet: Giant Reed.

(http://www.nps.gov/plants/alien/fact/ardo1.htm)

Else, Jesse A. 1996 Post flood establishment of native woody species and an exotic, Arundo donax, in a Southern Californian riparian system. MS Thesis. San Diego Street. 